Article

\title{
Ontological Boundaries or Contextual Borders: The Urban Ethics of the Asylum
}

\author{
Ebba Högström ${ }^{1,2, *}$ and Chris Philo ${ }^{2}$ \\ ${ }^{1}$ Department of Spatial Planning, Blekinge Institute of Technology, 37179 Karlskrona, Sweden; \\ E-Mail: ebba.hogstrom@bth.se \\ 2 School of Geography and Earth Sciences, University of Glasgow, Glasgow, G12 8QQ, UK; \\ E-Mail: christopher.philo@glasgow.ac.uk \\ * Corresponding author
}

Submitted: 10 August 2020 | Accepted: 23 September 2020 | Published: 12 November 2020

\begin{abstract}
What and where is 'the asylum' today? To what extent do mental healthcare facilities stand out as clearly bounded entities in the modern urban landscape, perhaps reflecting their history as deliberately set-apart and then often stigmatised places? To what extent have they maybe become less obtrusive, more sunk into and interacting with their urban surroundings? What issues of urban ethics are at stake: concerning who/what is starkly demarcated in the city, perhaps subjected to exclusionary logics and pressures, or more sensitively integrated into the city, planned for inclusion and co-dwelling? These questions underscore our article, rooted in an in-depth case study of Gartnavel Royal Hospital, Glasgow, opened as a 'lunatic asylum' on its present, originally greenfield, site in the $1840 \mathrm{~s}$ and remaining open today surrounded by dense urban expansion. Building from the 'voices' of patients, staff and others familiar with the site, we discuss the sense of this asylum as 'other' to, as 'outside' of, or merely 'beside' the urban fabric. Drawing from concepts of 'orientations' (Ahmed, 2006), sites as spatial constructions (Burns \& Kahn, 2005), the power of borders and boundaries (Haselsberger, 2014; Sennett, 2018), issues of site, stigma and related urban ethical matters will be foregrounded. Where are the boundaries that divide the hospital campus from the urban context? What are the material signifiers, the cultural associations or the emotional attachments that continue to set the boundaries? Or, in practice, do boundaries melt into messier, overlapping, intersecting border zones, textured by diverse, sometimes contradictory, bordering practices? And, if so, what are the implications?
\end{abstract}

\section{Keywords}

asylum; border; boundary; built environment; hospital; stigma; urban ethics

\section{Issue}

This article is part of the issue "Built Environment, Ethics and Everyday Life" edited by Mattias Kärrholm (Lund University, Sweden) and Sandra Kopljar (Lund University, Sweden).

(C) 2020 by the authors; licensee Cogitatio (Lisbon, Portugal). This article is licensed under a Creative Commons Attribution 4.0 International License (CC BY).

\section{Borders and Boundaries: Beyond 'Grey Belts'}

Borders are porous edges, boundaries are not. The boundary is an edge where things end, a limit beyond which no particular species must stray or, conversely, which it guards as do prides of lions or packs of wolves by peeing or pooping to tell others to Keep Out! The boundary marks a low-intensity edge. Whereas the border is an edge where different groups interact; for instance, where the shoreline of a lake meets solid land is an active zone of exchange where organisms find and feed off other organisms. (Sennett, 2018, p. 220)

This article is concerned with borders and boundaries in the urban landscape, seeking to understand them as ideational and material-conceived and perceived, on the one hand, and physical and functional, on the other. Our specific interest is what comprises, for urban planning, a somewhat neglected research area: the 'spaces' 
of mental healthcare institutions. Such spaces often appear to possess simple boundaries, sharply demarcating them from the residences, businesses, thoroughfares and other settings of urban life, but the reality may be different, with borders that are moveable, porous and, we might say, 'fractal,' in that what seems to be a 'straight line' at one scale turns out to be a much more complex, jaggy, twisting 'geometry' at another. Our aim below is to explore these matters and to draw out implications for the 'ethics' of urban planning, prioritising the 'voices' of people whose daily lives entail navigating the complexity of mental healthcare borders and boundaries, as well as negotiating everyday life in the urban environment.

In the quote above from Building and Dwelling: Ethics for the City, Sennett brings a natural-ecological distinction between borders and boundaries into the orbit of human communities, identifying the modern city as dominated by closed boundaries, "cut in segregated parts" (Sennett, 2018, p. 220), by traffic flows, functional zones and "guarded, gated communit[ies] inside a boundary wall" (Sennett, 2018, p. 220). Is it that simple? No, says Sennett, since there are things in-between, transitional and transgressive orders that ameliorate any crude distinction between the boundary's two sides. He continues with another pairing from the natural world: cell wall and cell membrane. The cell membrane "must at once let matter flow in and out of the cell" (Sennett, 2018, p. 220), but in a selective way so it gets what its needs to continue living, creating "porosity in dialogue with resistance" (Sennett, 2018, p. 220), a state of being overrun but able to absorb and hold. Sennett transfers such thinking into the realm of urban space, alerting urban planners to the dynamic relation between porosity and resistance. An open space is not per se porous and an urban wall made of stone is not totally solid: "Do not rely too much on the sheer materiality" is his message for the planners. He offers the example of historical city walls as "invitation(s) to dwell" (Sennett, 2018, p. 221), acting like membranes, border zones where transgressive practices are made possible passing between the two sides, with people moving seamlessly from one side to the other without taking any cognisance of the wall as barrier.

Although boundaries are generally understood as limits and conceived as lines (e.g., on a map), carrying with them a sense of division or separation in/of space, they are also social phenomena, "made by humans to help them organize their lives" (Popescu, 2011, p. 15) by regulating movement and often, indeed, with a high degree of porosity and permeability. Borders too can have quite obvious physical presence (e.g., the Berlin Wall), and at the same time carry a burdensome symbolism of past performances (e.g., the asylums; Anderson \& O’Dowd, 1999). To state, as does Popescu (2011, p. 15), that "borders are not fixed; they are transitory, and they always change in space and in time" concurs with Sennett's thesis about the city wall's porous character making possible the invitation to 'dwell,' contrasting the boundary's capacity for territorial exclusion/inclusion.
However, seeing walls as complex social constructions (Haselsberger, 2014) adds philosophical layers of belonging, exclusion and inclusion to their stark materiality. As such, fundamental ethico-political issues are at stake when considering borders and boundaries, at all scales from everyday life struggles of individuals to global political relations (Haselsberger, 2014; Paasi, 2009).

An important part of training as an urban planner (or architect) is to define the spatial features of any built, natural or urban landscape in terms of its borders, boundaries, edges and barriers, often from a topdown view over a base map perhaps, but not necessarily, confirmed by a site visit. Different urban structures mirror different conceptions of how to best organise the urban environment-infrastructure, distribution, security, health-and sometimes aesthetics become a driving force. However, few urban environments 'on the ground' are as consistent as planners envision, not least because pre-existing features in the environment are so hard to neglect (even if a tabula rasa position is in principle adopted). As cities grow, extant built constellations and natural formations have to be tackled and incorporated into the new urban layout. What to do with those fuzzy and 'unordered' spaces causes more frustration than inspiration for planners accustomed to an urban planning discourse whose ordering principles centre on consistency, control and continuity (Beauregard, 2005; Dürr, Egeb, Mosera, Neumann, \& Winder, 2020; Sennett, 2018; Sibley, 1981; Till, 2009). An example is when Jacobs dismisses scrapyards, manufacturing firms and other such sites as indistinct 'grey belts' (Högström, 2020, pp. 65-66; after Jacobs, 1961). Such places do not have a ready place in the diverse, vibrant, small-scale city culture that Jacobs envisioned. Similarly, institutions like hospitals (especially mental healthcare sites) are seldom integral to visions of the 'good city,' arguably reflecting a more-or-less acknowledged hierarchy of places with 'a spirit' and places without one (or with a negative, stigmatised spirit; Brook, 2000; Dyck \& Deighton, 2017; Moon, Kearns, \& Joseph, 2015).

This is a question of urban ethics, as the subtitle of Sennett's book indicates (see also Dürr et al., 2020). Who gets included in the urban realm, as a legitimate urbanite? What about the stranger, the newcomer or the one-time insider now troubled or troubling? What role is played in this respect by the material structuring of the urban milieu? By the built environment with its buildings, landscapes and infrastructural technical and social components, some elements of which themselves become coded as 'noxious' or indeed associated with outsiders? Ethical urban questions are tightly coupled with 'caring for place' (Metzger, 2014; Philo \& Parr, 2019), and with the interactions of people and 'lived space,' "concentrat[ing] on daily places and encounters in the urban life" (Söderström, 2017, p. 58). Such are big questions sometimes, if still too rarely, addressed by academic researchers, policymakers and planners: They lie provocatively in the background of this article. 
This article is organized as follows: after this introduction, we present the site of study, and its relation to urban and care landscapes, the empirical material and the methodological considerations. Thereafter, we outline our theoretical position, interfacing Ahmed's (2006) concept of 'orientations' with Burns and Kahn's (2005) claims about sites as 'spatial constructions.' This is then followed by the empirical section with its five subsections, all engaging with a specific dimension of bordering practices: straight line, imploding, exploding, no line and fractals. When concluding, we rejoin our findings with claims about how orientation 'positions' people, ending with speculations about how urban developments engulfing the site and bordering practices from everyday inhabitants may cause perceptions of the asylum as a place 'aside' to fade away, and as a result invite in mental healthcare institutions as full members of the urban fabric, no longer left as 'stigmatised territories' or the 'unclaimed' of the 'grey belt.'

\section{A Site Study: The 'Unclaimed' Asylum}

And what already exists is more than just the physical attributes of terrain (topography, rivers, roads, buildings) but includes also the various hidden forces that underlie the workings of a given place. (Corner, 2011, p. 90)
In what follows we take our material point of departure from the remains of a perimeter wall made of sandstone and concrete located in the western part of the city of Glasgow, Scotland, leading us to consider the borders and boundaries of a hospital campus (Figure 1). This wall was constructed to enclose the grounds of a 'lunatic asylum,' Glasgow (or Gartnavel) Royal Hospital, opened in the 1843. The hospital remains open today on the same patch of city ground, still widely perceived as sat 'within' its boundaries and 'secluded' from the surrounding neighbourhood: An 'outsider' in the city's built fabric, housing those often considered as outsiders to the 'normal' workings of urban civic society.

Indeed, Gartnavel as 'outsider' is suggested in Pacione's (1983) Glasgow-based study of neighbourhood communities. Pacione, searching for factors promoting social cohesion, sought to identify neighbourhoods in the city's 'greater West End' with established boundaries as perceived by local residents. Fascinatingly, a few areas came forward as 'unclaimed,' eccentric to what were perceived as neighbourhoods where people 'belonged,' including a few industrial sites, a former harbour area and our own area of inquiry, Gartnavel (Figure 2). Clearly outside citizens' perceptions of what constituted a 'neighbourhood community,' institutional areas like Gartnavel have a history of being perceived as empty, blanks on the map, or even as feared, stig-

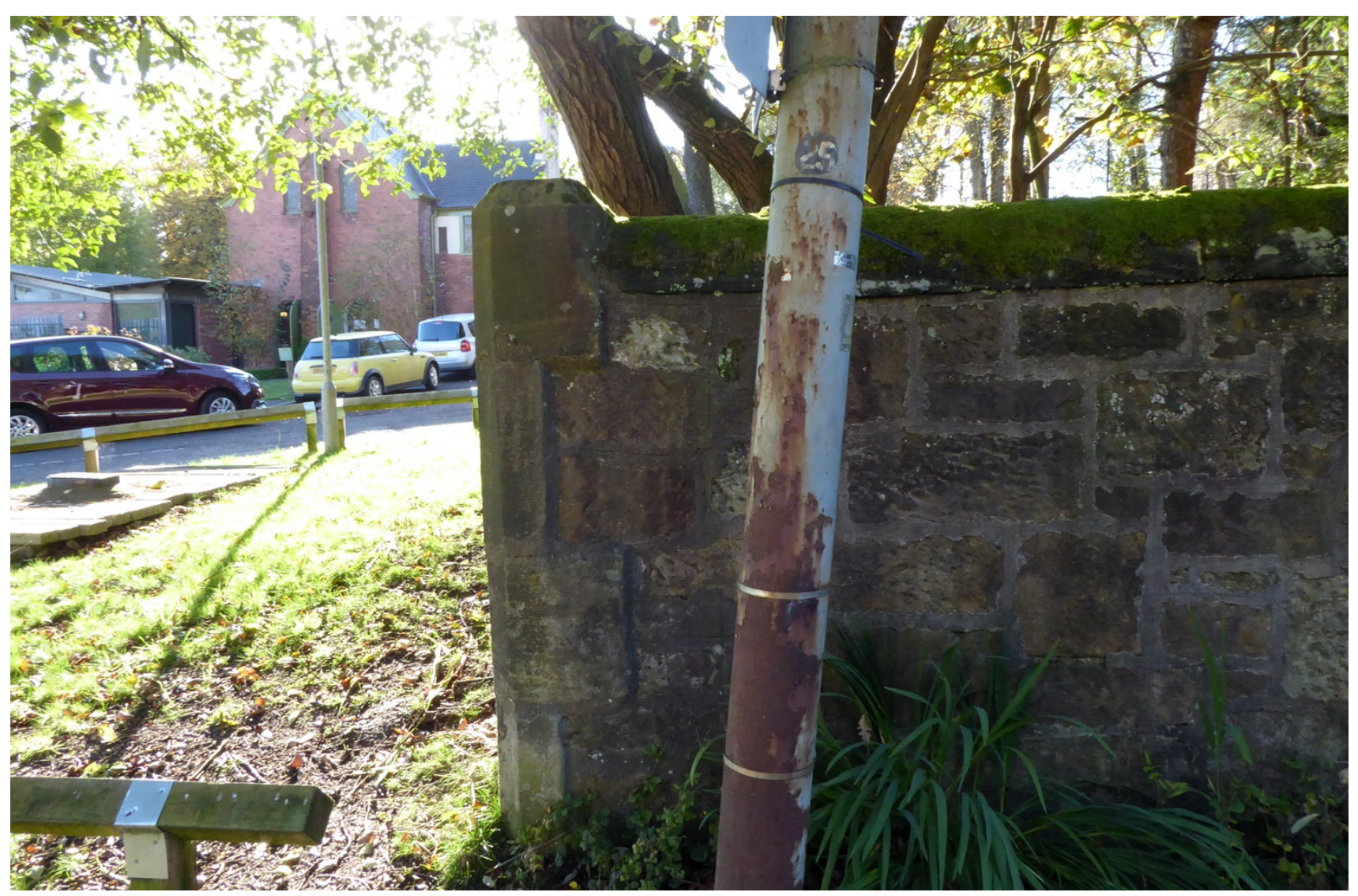

Figure 1. The perimeter wall once constructed to enclose the entire grounds of Gartnavel Royal Hospital. Source: Ebba Högström. 

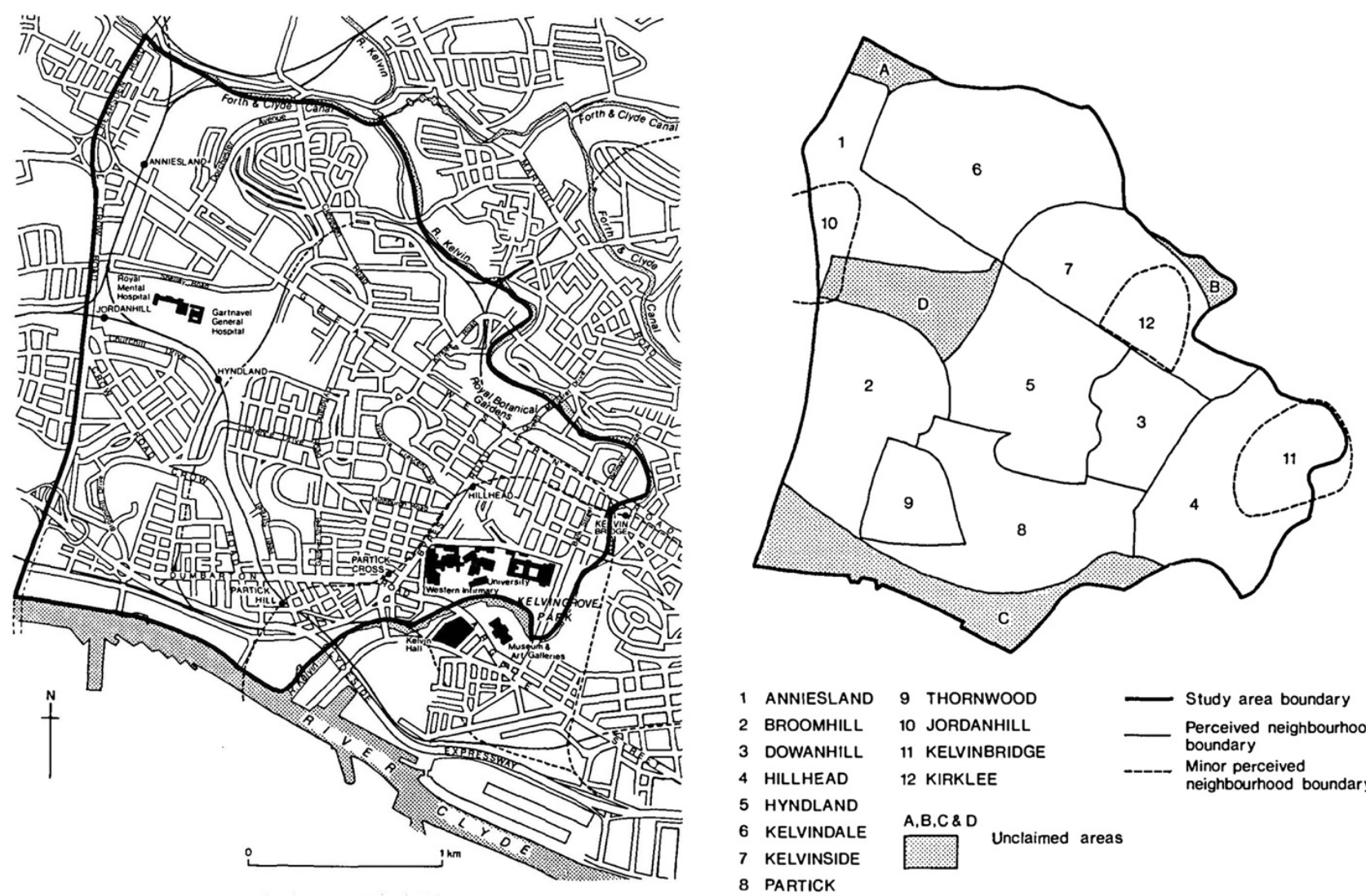

- Study area boundary Perceived neighbourhood boundary Meighbourhood boundary

7 KELVINSIDE

8 PARTICK

Figure 2. To the left, Gartnavel Hospital Campus location in the western part of Glasgow with the layout of the old asylum in black. To the right, Gartnavel as 'unclaimed space' (area D). Source: Pacione (1983).

matised territories (Goffman, 1963; Moon et al., 2015), whether in popular culture, citizen perceptions or urban planning discourse: "A place for those who mainstream society would prefer to shun, separate and segregate, rather than include" (Cornish, 1997, p. 106).

The original Glasgow Royal Asylum left the city's urban-industrial fringe during the 1840s for what was then an elevated location in a rural situation several miles west of the city. Over subsequent years, this 'old asylum' on the hill was reworked and extended, as well as being supplemented by new wards, units and treatment centres trailing around the slopes below the original Victorian buildings. Today, this former asylum area is characterised by a remarkable diversity of healthand-medical spaces, including a general hospital, cancer treatment centre, homeopathic hospital and more, as well as a state-of-the-art acute psychiatric inpatient facility opened in 2008. Parts of the grounds are used as a neighbourhood park, while urban expansion has changed Gartnavel's relation to the city, it now being located amidst residences, businesses and other civic facilities such as schools, sports facilities, train station, garages and shops (Figure 3).

Gartnavel's 'biography' is of course one version of a broader, complex history of mental health care, treatment, administration and spatial arrangements. It is a history of how different 'modalities' (Moon et al., 2015) have followed each other, oscillating between notions of progress and 'not-fit-for-purpose': e.g., care modalities (innovation in drugs vs. counselling therapies) and facilities modalities (huge institutions vs. small-scale facilities) and location modalities (rural vs. urban). An earlier phase of institutionalisation starting in eighteenthcentury Western Europe and North America was characterised by isolated, sizeable and often forbidding 'lunatic asylums' (Philo, 2004), whereas the most recent transition from the 1960s, deinstitutionalisation, saw a shift from large institutions, often located in rural areas, to small-scale mental health facilities run by state, voluntary and private sectors under the banner of 'care in the community' and usually localised in urban areas (Högström, 2018; Parr, 2008).

Our overarching argument is that such institutions bring the complex relation between built environment and everyday ethics powerfully to the fore. These institutions-and the 'areas' that they colonise-often 'live a life of their own,' made possible by powerful owners (e.g., UK National Health Service) in tandem with operational demands (e.g., constant alertness to change), which in turn renders it difficult for local planners to enrol these areas into local planning regimes. These areas appear as 'outsiders' in contemporary ideals of dense and vibrant city life, a specific dimension of which is that institutional health care sites are seldom the primary choice of assignment for planning students' projects, not being considered sufficiently interesting as 


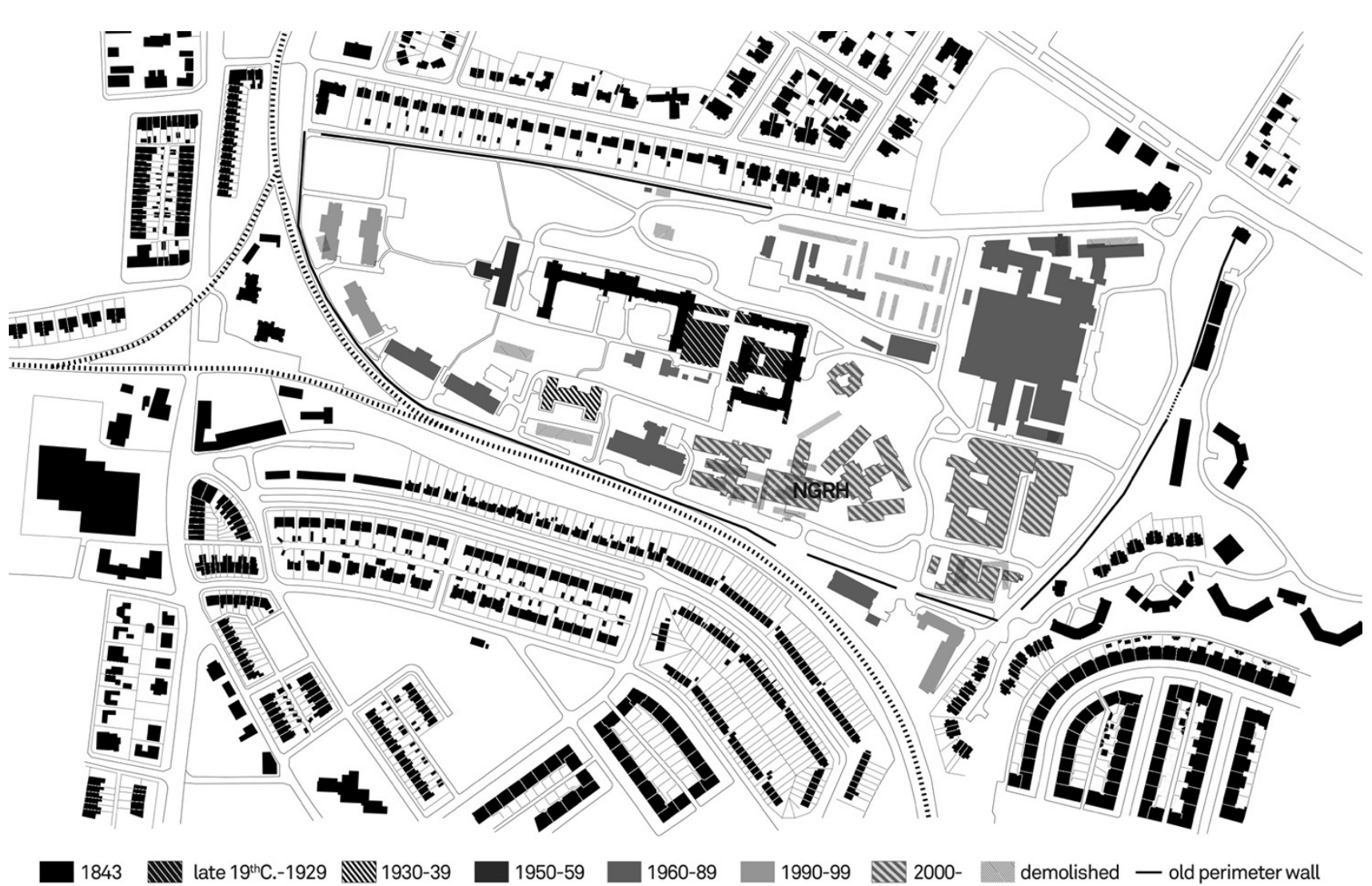

Figure 3. Site plan over Gartnavel Hospital Campus as it looks today is located amidst residences, businesses and other civic facilities. Since the construction in $\mathbf{1 8 4 3}$ of the 'old asylum' on the hill it has been reworked and extended, as well as being supplemented by new wards, units and treatment centres trailing. One of the most recent developments is the new psychiatric clinic, New Gartnavel Royal Hospital (NGRH) and with its opening in 2008 the last patients moved down from the asylum on the hill. Note: Site plan by Andrea Gimeno Sanchez.

they do not 'fit' with the idea of urban mix in both formal and functional aspects (Dovey, 2016). Haselsberger $(2014$, pp. 505, 523) urges planners and planning scholars to confront the challenge of thinking and working "within multiple hard, soft and fuzzy spaces in parallel" and being awake to "multiple relational geographies," and hence to this call we would add that the "fuzzy spaces' of the city asylum or mental health campus (and other similar areas) must feature when contemplating such 'multiple relational geographies.'

This article is based on the research project Psychiatry in transition: Discourse dwelling doing, an 18-months EU-funded inquiry offering an experiencebased and 'spatialised' perspective on European psychiatric transition, with Gartnavel as case study. The objectives of the study were to nuance the history of asylums and contemporary mental health care (also comprising 'care in the community') by gathering the voices of people with lived experiences of mental ill-health or having worked or in other ways had a relationship with this place (e.g., neighbours). As part of the nuancing, we analysed the wider urban constellations in which this hospital campus is located.

During May 2017-April 2018, we completed 33 indepth qualitative interviews with primarily patients/ex- patients, staff, volunteers and others, besides field walks (transect walks around the site), building visits and an art workshop with inpatients. In the interview quotes participants are designated as follows: A-patients, B-staff, and C-volunteers. Patients were recruited through Gartnavel clinical staff, following strict ethical protocols and only including individuals reckoned to be 'well enough' to participate, while ex-patients were recruited through psychiatrists, voluntary services manager and patient representative on our local research implementation group. Staff (of various kinds) and volunteers were also recruited via the local research implementation group, supplemented by presentations and invitations given to clinical, nursing and ancillary worker cohorts at Gartnavel Royal Hospital. We were very much beholden on whoever was prepared to speak to us, and hence cannot claim the 'representativeness' of our sample beyond ensuring near-parity between each of the principal groupings participating. Interviews followed a loose schedule of topics, with master questions left deliberately open-ended, most then becoming conversational with participants typically becoming comfortable with steering the precise subject-matters being addressed. We generated an enormous amount of empirical 'data,' including more than 1,000 pages of interview transcripts (besides fieldnotes, 
images, sketches and maps) which we have rigorously processed by deploying long-established hermeneutic procedures of close reading, re-reading and 'coding up' of transcripts attentive to emergent themes spoken by 'triangulated' by at least three participants (usually more; Cloke et al., 2004, Chapter 10). Our epistemological position is sceptical about the value of quantifying such 'data' or correlating it numerically with other variables, but in what follows 'many' of our participants equates to roughly more than $50 \%$ of the sample, 'some' to circa $25 \%$ and 'a few' to three or four respondents.

Using our Gartnavel study, then, we discuss the notion of the asylum as 'other' to, as 'outside' of, or merely 'beside' the urban fabric. Such a conception arguably continues to fashion an ontological narrative long after the original asylum has been vacated-when the 'old asylum' on the hill gets decommissioned-and the patients and staff are located elsewhere in less bounded realities (both on and off-site). Indeed, to anticipate, many of our participants were alert to the history of Gartnavel, and of asylums more generally, in which segregation was supposedly desired and enacted, even as they queried the extent of-or need for-such set-apartness in their own latterday experiences. After having set out the context and methodology of our study and before diving into our empirics, we will now move to the section where our theoretical position is outlined.

\section{Orientation Matters, Site Matters}

Orientations are about the direction we take that puts some things and not others in our reach. (Ahmed, 2006, p. 56)

We draw from Ahmed's theoretical concept of 'orientation,' how orientation directs us towards some things while leading others to stay out of sight (also Hannah, 2019). Ahmed (2006, p. 1) claims "to be orientated is to turn towards some objects more than others." Such a 'turn' helps in finding our way as we tend towards objects we recognise. Landmarks or other well-known signs give anchoring points, and, by gathering on the ground, they create a ground upon which we can also gather. Ahmed (2006) asserts that social orientation shapes spatial orientation. Such a social orientation might be understanding what the asylum is, has been, and could become in the future, a contentious subjectmatter loaded with different meanings. It ties into a comingled socio-spatial orientation fusing socialised senses of a place and more immediate phenomenologies of spatial encounter, shaping how 'we,' everyone involved, gather at and around the asylum-as-place-in-the-city. This orientation shapes our perceptions and conceptualisations as we gather at its grounds: a place wilfully set apart, as 'hortus conclusus' (Aben \& De Wit, 2001), a deeply perceptual and markedly material 'protected' space akin to others emerging through time and across "different scales from the city's structures to small secret gardens" (Anonymous Reviewer, September 2nd, 2020) or, a site with border zones, a city membrane structure (Sennett, 2018), where movements, events, transactions flow between sides/sites? Or, as in Pacione's study, maybe we spy an orientation leaving the asylum as the unclaimed area, belonging to no one, a 'nonneighbourhood' (Augé, 1995), a 'grey belt' place (Jacobs, 1961). Such orientations affect what comes into view but are not simply given, "as they are effects of the repetition of actions over time" (Ahmed, 2006, p. 23). We tend towards a direction, pointing to the future, to what is not yet present; and yet, Ahmed (2006) continues, orientations are shaped by what is behind us, creating a loop between what is towards and what is behind. We make sense of the world by orienting in certain directions: These orientations, the sociocultural nexi of spaces and places, are shaped by what has taken place as well as shaping future events.

We also draw from the understanding of sites as 'spatial constructions' (Burns \& Kahn, 2005). Space as 'lived,' material and discursive has interested a wide range of scholars in geography, planning and architecture from perspectives of, e.g., spatial justice (Harvey, 2009; Lefebvre, 1991; Massey, 2005), assemblage thinking (Amin \& Thrift, 2002; Dovey, 2016; Farias, 2010) and more-or-less experience-based constructs (Ballantyne, 2004; Crouch, 2011; Grosz, 1992; Palasmaa, 2013). Drawing from these spatial understandings, Burns and Kahn (2005) explore 'site matters' in material, conceptual and methodological realms with the ambition of tying site "as a conceptual construct-'site thinking' - to the grounded site as a physical condition-'thinking about a site"' $(2005$, p. x). To perform site thinking, however, entails an exploration of one's own normative assumptions. Echoing Ahmed (2006)-where we come from and where we are heading forms perceptions and consequently conceptions-Burns and Kahn (2005, p. viii) contend that "[e]ach specialised area of physical designarchitecture, landscape architecture, urban design, and urban planning...construes the location of its activities and practices overtly and tacitly through its own normative approaches." For example, site analysis is part of the urban planning and design profession, typically a taken-for-granted activity which means, generally, formulating a site's basic spatial features. In so doing, the site to be analysed is "too often taken as a straightforward entity contained by boundaries that delimit it from the surroundings" (Awan, Schneider, \& Till, 2011; Burns \& Kahn, 2005, p. x), construing the site as simply 'there' waiting to be discovered and its context as uncomplicatedly 'there' too, merely a repository for the gathering of relevant data. This way of representing space as well as people has normally been regarded as value-free and neutral, as if the plans, maps and texts are merely accurate and valid representations of a measurable world 'out there' (Hillier, 2008). Yet, what Burns and Kahn (2005) argue, is that there are no such things as site or context per se waiting to be discovered, mea- 
sured and analysed. Instead, they understand 'the site' and 'the context' as constructions, as narratives written and rewritten, told and retold by a plurality of 'voices' (Hillier, 2008; Sandercock, 2003). The 'site' is a 'hybridity,' at once "a real construct (of nature), a narrated construct (of discourse), and a collective construct (socially constituted)" (Burns \& Kahn, 2005, p. xxi; see also Amin \& Thrift, 2002; Lefebvre, 1991; Massey, 2005). In similar vein, Dovey (2016, p. 4) contends "the city [as] a palimpsest that emerges as the result of multiple layers of creativity, erasure, history, politics, economics and technical invention," possessing strong linkages to the sublime and sensory experiences "that overwhelm us" (Dovey, 2016, p. 4). In short, where does the physical end and where starts the perceptual? With this provocation and with Burns and Kahn's claim that "site is best viewed from points in between" (2005, p. xxiii)-supported by Hillier's vision of a multiplanar theory of planning that starts in the middle, with a multiplicity of different and often agonistic, if not antagonistic, desires, needs and wants" (Hillier, 2008, p. 43)-it is now time to dive into 'the middle of' our empirics.

\section{From Spatial Ontology to Bordering Practices (at the Asylum)}

\subsection{Straight line}

A walk like this, from north to south, means we are experiencing barriers, we must take long detours. However, the wall is not the main barrier, it is the urban structure, the long blocks, and the railway. (Authors' field notes, November 9th, 2017)

One of our key walks traced the old perimeter wall, this most material manifestation of the asylum-city boundary. In simple physical terms alone, this boundary is now distinctly fuzzy in places, making it hard to identify any clear-cut dividing campus-neighbourhood boundary (Högström \& Helms, 2019). This fuzziness owes to the partial demolition of the wall, but also to the influx of new constructions overtaking the wall's location (e.g., roads, buildings, railway). The gatehouse at 'the main gate' on Great Western Road is now demolished, although as recently as 1988 "[y]ou ...entered...through the front gate....The back gate was open for a period of time. So you could come in the back or in the front. It was open but there was a wall still demarked round about it" (B1, nurse). Today, there is no longer any 'gate keeper' controlling entrances and exits; instead the traffic junction controls movement by its lights, while the back gate on Crow Road is always open to deliveries, cyclists and pedestrians.

The overall campus has changed over the years, but as late as the 1980s the old buildings were still fully occupied, a thriving but enclosed hubbub:

There was just under a thousand patients at that point....So in 1988 there was a-it felt...busy...it felt like a village in itself, that's the only way I can describe it. Obviously it had the wall around about it. (B1)

Today, the old buildings are partly inhabited with the National Health Service administration (West House), partly empty or lying derelict (East House; Figure 4), and such 'phases' cannot but fuse with differing orientations towards where the boundaries lie. For the above participant, the 'wall around about,' a mental construct as much as a material one, remained-for many, if not for him personally-one between the 'mad' and the 'normal':

The mystique was still there round about mental illness, you know? I think maybe people still felt that, 'Oh God, once you go over that wall there, everybody in there is going to either look a bit different or is going to appear different to you.' Maybe people still had an image of people that perhaps had mental illness were screaming and shouting all day. (B1)

The quotes above and following fold into a 'straight line' construct, meaning here a clear asylum-city demarcation materialised in the old perimeter wall, accepting it in bold (as a significant ontological divide) or in dots and dashes (rendering it more ontologically fractured).

On the question where the wider community 'starts,' meanwhile, this participant answers: "Outwith the grounds of the hospital, I would say" (B9, occupational therapist). This conception focuses on the site/grounds and also infers a standard 'straight line' depiction of the asylum-city boundary:

There is the 'here and now' and the 'then and there'...[T] here's a sense of respite being here. You're away from the world and...it's a bit like when you go on holiday and the world is back there and you are over here, and you're not having to deal with your worries and problems. (B9)

For someone to be admitted is to put a temporal and spatial boundary around their troubles. Time and space are seen here as tightly coupled inside/outside concepts: 'asylum in here'/'world out there,' with, in this instance, the former equating to a kind of sanctuary or retreat, a less stigmatising model than that of 'mad' asylum inmates walled in to protect neighbouring residents.

\subsection{Imploding}

Another series of quotes hints at an 'imploding' of the asylum-city boundary, dragging the latter, the wider community, on to the site itself-within the old perimeter walls-and effectively closing it around a really quite narrow set of spaces associated with the newer inpatient provisions (Figure 5):

Interviewer: Where do you think the boundaries of Gartnavel Royal Hospital are? 


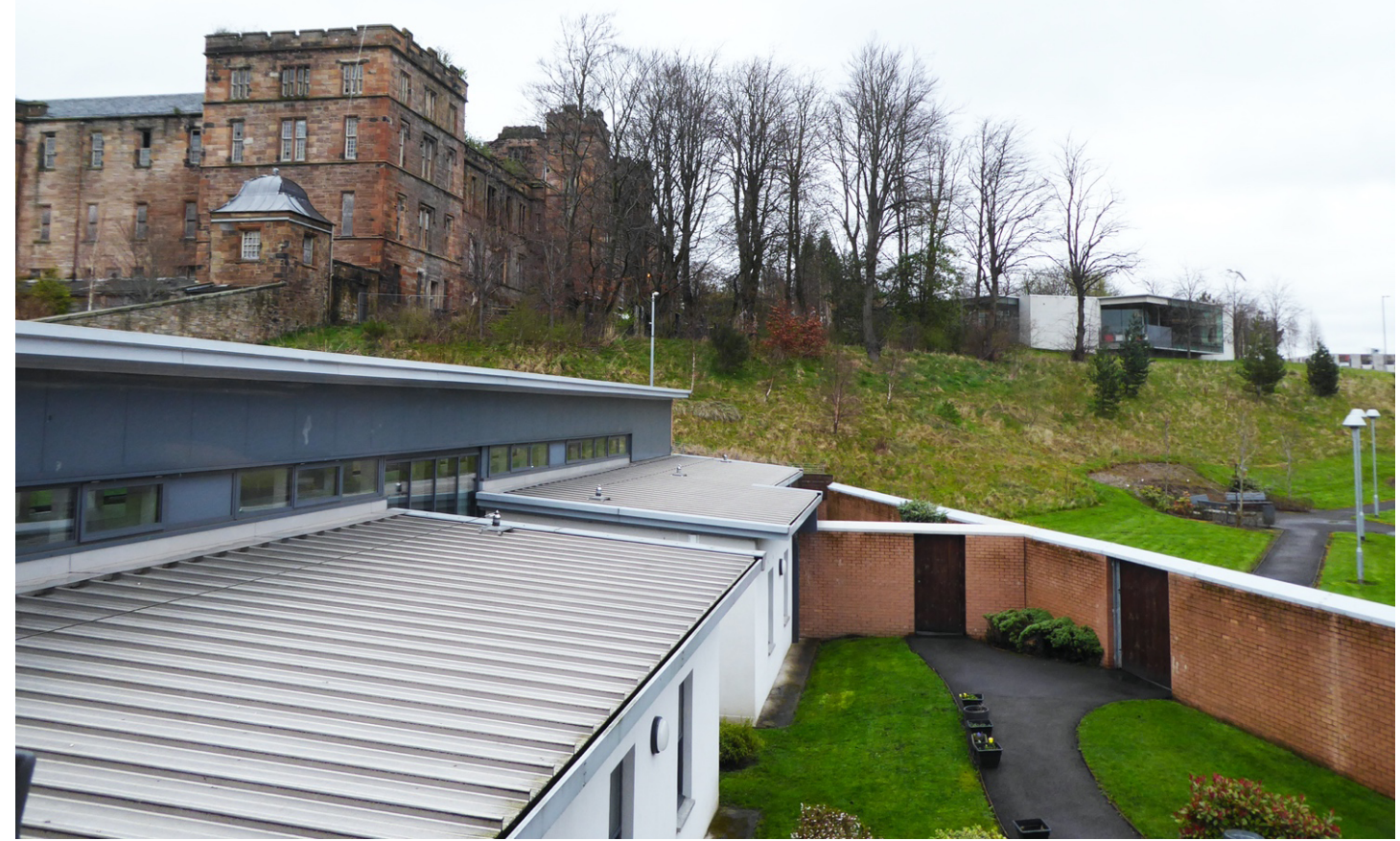

Figure 4. View from NGRH towards 'old asylum' on the hill and its empty and derelict East House. To the right, behind a curtain of mature trees, Glasgow's Maggie's Centre (opened 2011) is crouching. Source: Ebba Högström.

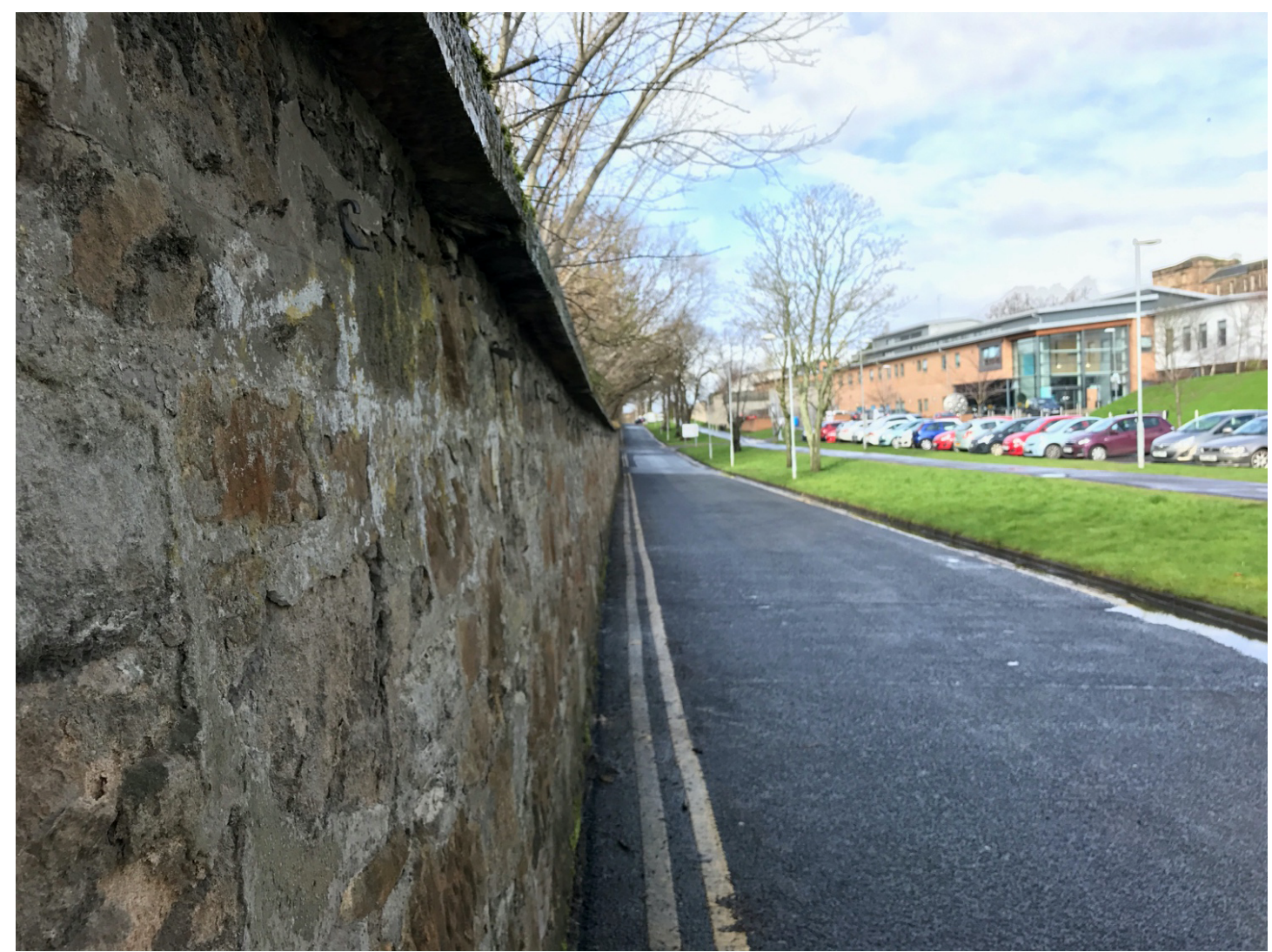

Figure 5. Perimeter wall and the new psychiatric facility at Gartnavel, designed by Macmon architects. Source: Ebba Högström. 
Respondent: Well I suppose there is the historic view which is that it's all around the old sandstone wall and all the way to Great Western Road...that's all Gartnavel Royal Hospital site. But now there's Gartnavel General Hospital, and there's the Health Board site and things, so the site has become...more populated with other services and things. So now I would say that Gartnavel Royal Hospital is this [new] building, probably, and maybe the wards along there although they are slightly different as well.

Interviewer: So then when you step outside this building you're out in...

Respondent: A public space, yes. (B13, psychiatrist)

This exchange captures the 'historic view,' taking 'the old sandstone wall' as the notable boundary, before developing a more sophisticated sense of a boundary complicated by all the newer non-psychiatric accretions across the site. But, rather than then arriving at an interpretation of an 'open' site where asylum and city admix, this participant settles on a still starker socio-spatial orientation in which the meaningful boundary between mental hospital and what is beyond implodes into the heart of the site, effectively ending up at the front-doors of the newest inpatient facility. The result is an implosion of the boundary into merely a distinction between indoors and outdoors, private and public spaces, the psychiatric clinic building and the urban fabric.

\subsection{Exploding}

Other quotes hint at a quite opposite 'exploding' of the asylum-city boundary, stretching it off the site itselfbeyond the old perimeter walls-and effectively distributing it around a diversity of spaces, psychiatric, medical, civic, residential and more, that would never otherwise be labelled 'Gartnavel.' Such quotes disclose easy movements by all manner of participants (patients included) across the 'historic' boundary, creating permeability/porosity that was not there before, certainly not for patients or some categories of staff: "I like taking a look, walk up...here [where] a generator is, [and] I used to stay on top of a roof. I stayed up there for a month or two months" (A2, patient).

During periods when discharged from the asylum, this participant stayed, sometimes for long periods, living in the grounds, one time in a tunnel under the old asylum and another on top of a small power-generation station. He would walk down to his grandmother's house nearby to have breakfast, steal pints of milks from affluent parts nearby and beg sandwiches from local shops. He covered quite an area by walking and used the grounds, and indeed the whole neighbourhood, for quite other purposes than the planners intended. He transgressed boundaries with his haphazard bordering practices (in terms of socially acceptable behavior, breaking into buildings and 'sleeping rough'), and yet he also exercised a 'caring for place,' mirroring a sense that the place cared for him, "with all the nurses around" (A2).

Other instances of exploding the boundary are even more stark:

A lady patient and I went down to Byres Road [some distance off-site] and she was quite full of herself, you know? And she done this, so I said to her one day, 'Why don't we go and fly to Ireland?' So, we went down from here, got a taxi down to the airport on a Friday night and flew down to Dublin. (A2)

This story reflects that the asylum was not anywhere near as enclosed-as policed, we might say-as it appeared, or that might commonly be supposed, and that there was a porosity rendering it possible for people, vigorous and wily, to challenge the rules and regulations. It also reflects on how the world 'outside' was not only a possibility, it was a reality into which one might disappear if the opportunity arose. The world 'outside' in this case stretched far beyond the neighbourhood and the city as a whole.

\subsection{No Line}

For some participants, there was arguably no line at all, straight or curvy, imploded or exploded. This participant, a junior doctor, having worked at the adjacent general hospital, knew little about the site and its history before commencing work at the new psychiatric facility: "I had never been around to the psychiatric department. I'd got as far as the Beatson [cancer centre on the campus], so I knew there were some new buildings there but I had never been around here" (B14, junior doctor).

She is not reproducing the asylum as an enclosed entity simply because she does not know what to reproduce: Before arriving in her current post, she knew that there was a building 'down there' from the old structures on the hill, but that was about it. Hers is a quote betraying a lack of familiarity with-and, someone not greatly attuned to-any dramatic asylum-city boundary, nor indeed having any historical knowledge of the asylum. For her, the boundaries in question, insofar there are any, are solely ones demarcating medical from urban space.

Another example comes from a young inpatient during her first time at Gartnavel, who knew nothing about the history of the site, nor of the old asylum upslope:

Oh is that what that is? I was wondering. Me and my dad went past that and thought...and I just looked up and said, 'What is that?' It looks really nice. It's a nice building; I don't know anything about it though. (A10, patient)

She had for the most parts stayed in the new hospital, cocooned within the walls of that building, lacking awareness of Gartnavel as an overall site with any kind 
of boundary around it (historical, functional, administrative, etc.).

\subsection{Fractals}

When considering implosions, explosions or even a perceived absence of the asylum boundary, questions about its porosity in both directions, from 'outside' to 'inside' and vice versa, crowd into view, challenging any simple sense of any straight line laying down-consistently, fixedly - the asylum-city boundary. Hence, a better picturing may be, as mentioned at the outset, fractal, reflecting the claim that "[f]ractals are...objects...which can be described as irregular, coarse, porous and fragmented" (Madelbrot, 1977, as cited in Dauphiné, 2012, p. 1). Pursuing this notion further, we would emphasise how Gartnavel staff and volunteers explicitly scramble the boundary, inviting in the wider community through public events such as the annual Over the Wall fair (Figure 6), running gardening groups and by encouraging people to walk their dogs or play in the grounds: "We're trying to do away with any mystique round about that there is something strange happening in here" (B1).

This openness gets noticed by others: "I think it's nice that people come and walk their dogs and stuff. So you do feel at least a little bit sort of connected to the outside world" (C3, volunteer). Relatedly, as expressed by another participant who grew up locally:

I've been in the grounds about a thousand times.... used to play football down at the front....We got told off every time but there was about twenty or thirty of us at school playing. So that's maybe twenty years ago. (A4, patient)

This respondent saw patients walking in their dressing gowns and he and his friends used to laugh at them. He knew it was a mental hospital, but predominantly for him it was a place of recreation, a place effectively belonging to the neighbourhood where he could play football. For him, therefore, both a 'straight line' against the stigmatised inmates and an entitlement to jump the

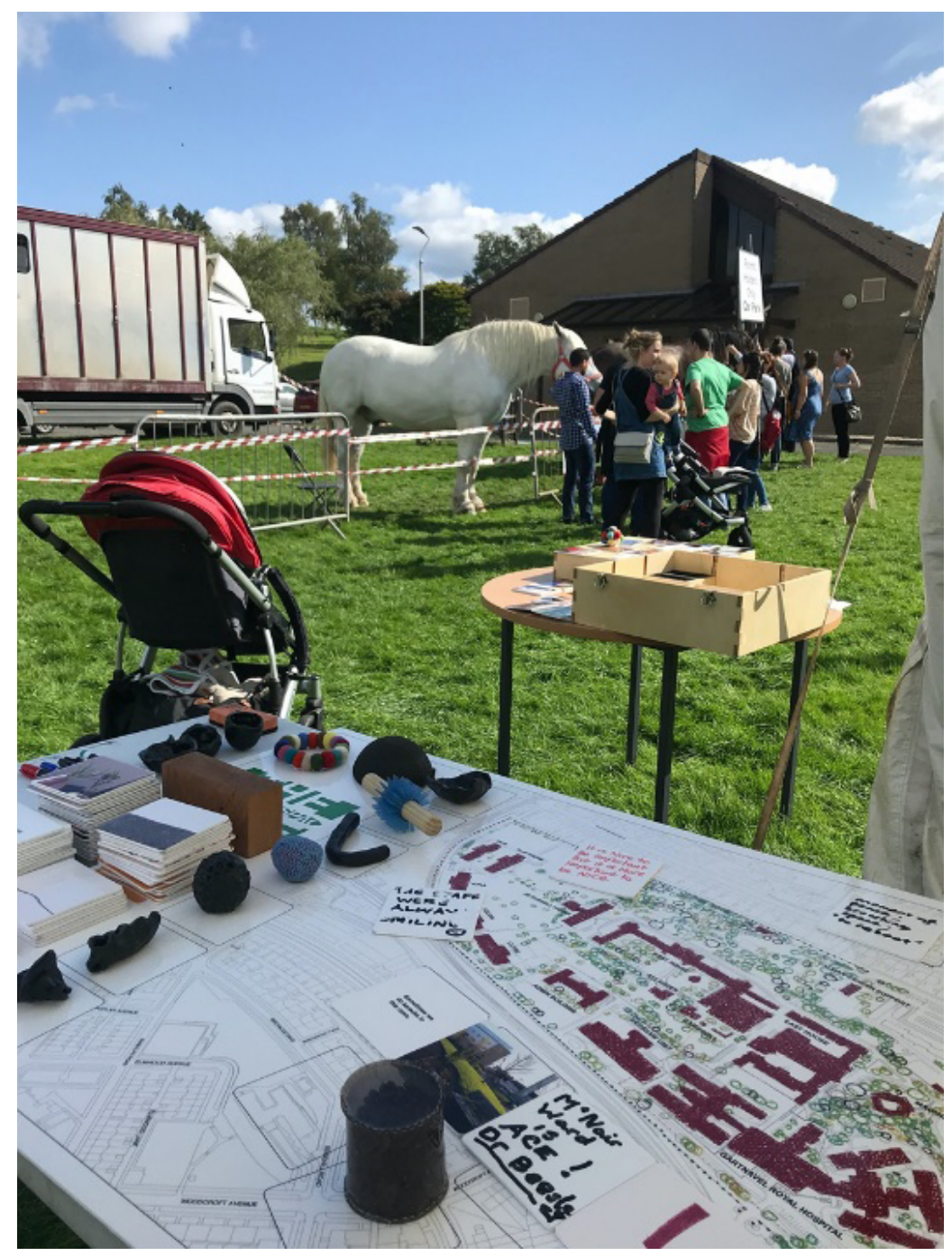

Figure 6. The annual festival Over the Wall at the hospital grounds in August 2018 with horses, theatre, music among other things. In the foreground our pop-up exhibition The Gart Game. Source: Ebba Högström. 
wall for football jumbled together: a marked boundary scrambled by truant bordering practices.

On the matter of the site's relation to community and urban milieu, this participant offered nuanced appreciations of both separation and connection:

It's extremely well connected to the transport networks....So I don't think of it as being secluded in the sense that it's cut off from anything. But I think of it as being secluded in the positive sense of it being this nice, leafy green space that feels, you know, a little bit separate and quite calm. (C3)

She reflects that the psychiatric hospital would have felt much more secluded if it had been set in a 'pure' mental health campus with no reason to visit for others than staff and patients. The blending of different care operations here renders stigmatised perceptions of mental health care less salient: "It just feels part of the larger hospital network to me" (C3). This blending also goes for people moving around the campus: "I don't know [if] they're a patient, or if they're a member of staff on a break or they're a random dog walker...or they're somebody from the general [hospital]. You don't know" (C3). Even the perimeter wall 'fades' away in this blended site: "I've not really thought about the fact that that was probably used to keep everybody in at one stage" (C3).
The accessibility from different directions, the mix of people and the openness to using the grounds for diverse reasons make the site appear as a fluid border zone, not one sealed behind an enclosing boundary:

Well, I think of it as separate to the neighbourhood in the way that any establishment would be. But it's still open for people to walk through and stuff, so I don't...think of it as separate in a bad way....So it feels connected and people can move through it and out it...as opposed to being just some big fenced-off campus where you just come in a main gate. (C3)

The site's capacity to be connected but yet secluded arises in many interviews and walks: a warren of fractal places within the porous site, not always easy to find (like those favoured by the site's 'rough sleeper'). The 'Walled Garden' is such a place (Figure 7):

It's kind of like a secret garden: if you don't know where it is, it's quite a nice surprise to find it up here. And it's quite a sanctuary. It's secluded a little bit and peaceful. You feel like you're not on the hospital site anymore. (C4, ex-patient and volunteer)

This participant had worked at the general hospital before getting ill, but never visited this 'secret garden.'

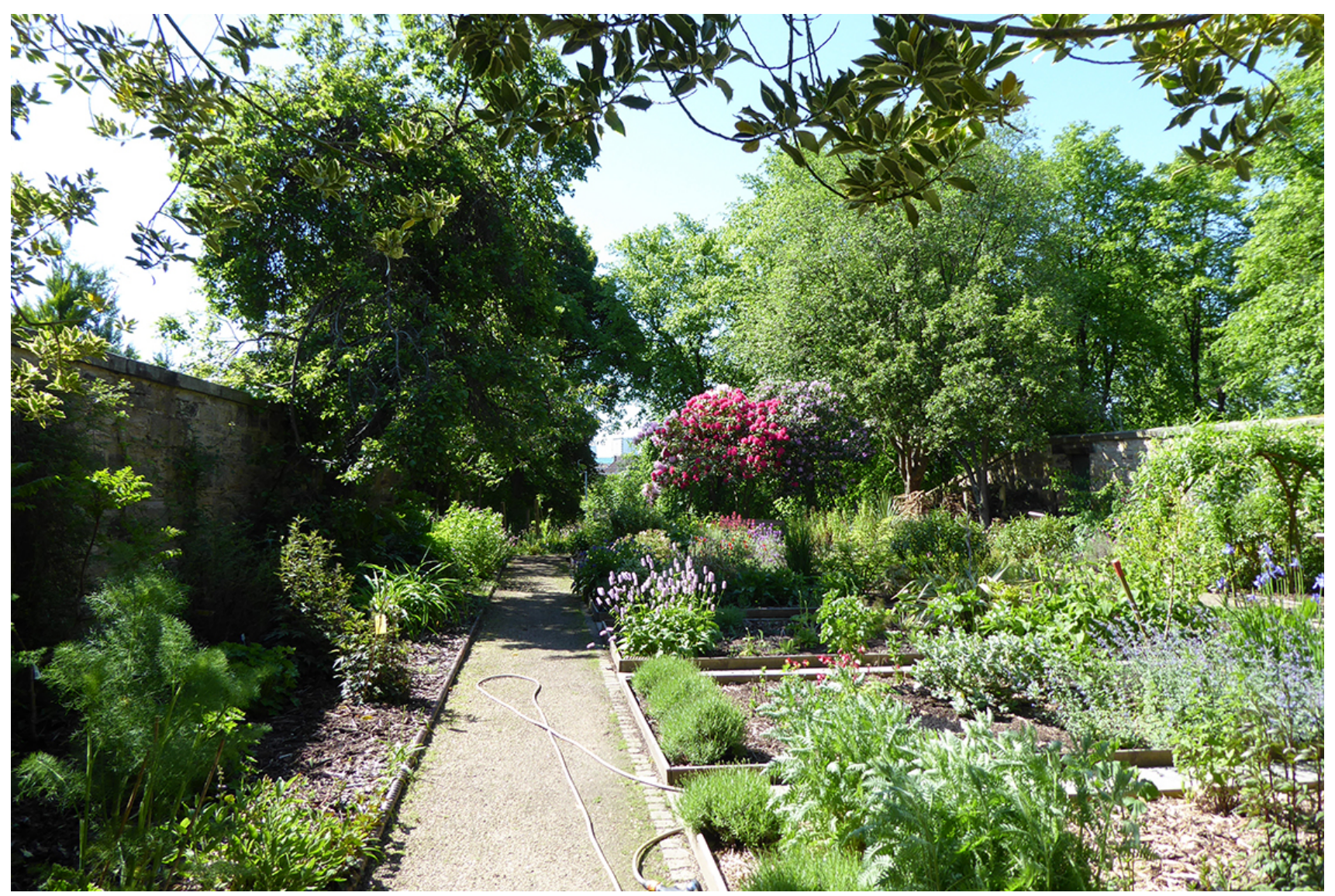

Figure 7. The walled garden at the old asylum. Source: Ebba Högström. 
In retrospect, she pondered whether it would have been beneficial for her then to have done so, "just [to] get a mental break from work" (C4), but she had not known of its existence, hardly too the grounds or the old buildings either. Now it is all familiar, even if it is the gardening and sociality of her gardening group that she directly values, the old asylum merely a background presence (Figure 8 ).

We hence bring our empirics to a close by now electing to view Gartnavel's boundary as fractal, a border zone or, maybe better again, a kaleidoscope-a constantly changing space-time pattern (Högström, 2012)of overlapping zones characterised by differing bordering practices (Haselsberger, 2014), certainly not a simple enclosed entity. We thereby return to Sennett's urban space characterised as "porosity in dialogue with resis- tance" (2018, p. 220): An array of spaces of different registers, intersecting, sometimes contradictory, emerging out of the messy realities of how we make it possible to orient ourselves (Ahmed, 2006) in and to the world, the city and into its areas unjustified labelled as unclaimed.

\section{Asylum-City: Curvy Lines of Bordering Practices}

We have worked towards an interpretation of the variegated mental healthcare campus-and its historical antecedent, the asylum - as a 'site' of much more variation and ambiguity, a "hybridity" (Burns \& Kahn, 2005, p. xxi), than is initially given to the imagination (with or without knowledge of historical twists in mental healthcare), and one more connected to the urban built envi-

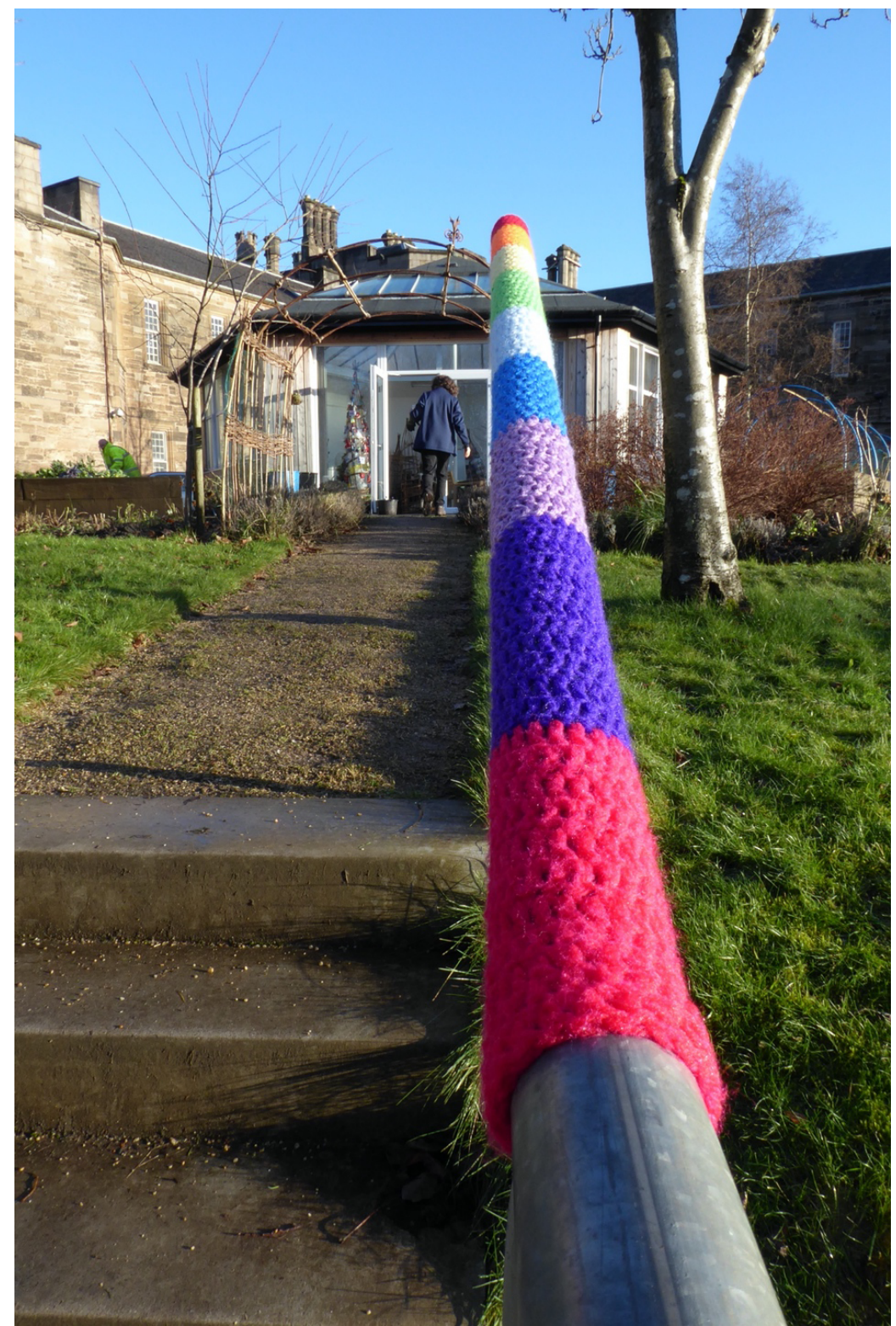

Figure 8. Just besides the Walled Garden, with the old asylum's West House as background, the gardening groups have their greenhouse and cultivation boxes. Someone thought the handrail needed a protection against the cold metal. Source: Ebba Högström. 
ronment than is generally perceived. The 'orientation' towards conceptualising the likes of Gartnavel as 'institutional sites' disconnected from the rest of the urban environment remains strong, continuing to feed perceptions of less valued sites as 'problems' disturbing an otherwise consistent and ordered urban structure. To map closely an area such as ours, through embodied onsite investigations and in-depth interviews with people involved with the site, reveals a much richer repertoire of 'site constructions' (Burns \& Kahn, 2005; Dovey, 2016; Hillier, 2008) than might have been anticipated. This repertoire is not to be seen as solely internal, as only relevant for the spaces inside the remains of the perimeter wall or for administrative boundaries; rather, the site constructions are overlapping, blending, merging and even sometimes divided by other means (e.g., railway and housing blocks) than the ones once constructed to border out the society from the asylum. All of which questions a 'site thinking' of enclosed discrete sites located side-by-side in neat order.

From our empirical investigations, intriguingly different perceptions arise about the boundaries of Gartnavel. For some it is the line of the old boundary wall; for others it is the entrance area to the new building; and many tell of a place much less bounded, less sealed-off from the surrounding city, than was true of earlier years. Many of our participants convey 'spatial stories' that reinforce a discourse of enclosure: Of a place 'beside,' where the remains of the original perimeter wall are indeed still perceived as the boundary line. We have also listened to accounts of 'breaking the line' through transgressive practices ('sleeping rough at the grounds'). Some tell of an imploded site, where perceptions of a bounded site are totally dismissed; others have no opinion of a bounded site at all (maybe their knowledge of the past is limited). Lastly, quite a few intimate a multifaceted, fractal and porous site, a site that has gained from the blending in of other operations, leading to further blurring of the asylum-city boundary and to the emergence instead of a border zone meaning it is not obvious to state where mental healthcare ends and community starts. This outcome is due to both deinstitutionalisation and city expansion, having played equal parts in the 'blending in' of built structures and functions and consequently the blurring of boundaries.

Urban planners and designers, even though working and often feeling stuck in a political domain hard to master, have an important mission in working across the professional biases clinging to many sites. What spatial stories of 'bordering practices' could replace the 'straight line' thinking of ontological boundaries? Would it be a deeper engagement in places and spaces, by those professionals working in the spatial 'industry' (i.e., urban planners, urban designers and architects), so as to 'construct' sites as the multiple, temporary and fluid constellations that they seem to be? These are significant claims to voice in relation to emerging work on ethics and the built environment, in planning, architecture and geog- raphy; to increase awareness of what is at stake when planning for inclusive living environments or, in Sennett's words, working towards 'the open city'; to adopt a 'site thinking process' challenging "a modern epistemological framework that privileges clear categorization" (Burns \& Kahn, 2005, p. xxi).

Ahmed (2006, p. 59) talks about the relationship between how we look upon the world and its objects and how we use these objects, asking how "what we do do, shapes what we can do." She entangles orientations' past dependencies, to histories, and how these pasts always work as horizons for how we act in the future. Is it possible to orient in another direction and to understand this place-here the asylum or psychiatric inpatient site seconded by an array of other care operations-as a connector, incorporating and incorporated into the urban fabric in its own right: A site taking part in society, in the urban structure, in the city as any other place; border zones fluctuating between order and disorder, to paraphrase Moser and Law (1999), between good passages and bad passages.

\section{Acknowledgments}

The research project from which this material originates was funded by the European Commission Marie Sklodowska Curie Individual Research Fellowship (706026-GART-PSYSPAC-H2020-MSCA-IF-2015). The authors thank the management of Gartnavel Royal Hospital, Glasgow, UK, for making this research project possible, especially all the participants of the project, many of them staff and patients at the hospital, and the Local Reference Group. The authors also would like to thank the two anonymous reviewers for their valuable feedback.

\section{Conflict of Interests}

The authors declare no conflict of interests.

\section{References}

Aben, R., \& De Wit, S. (2001). The enclosed gardenhistory and development of the hortus conclusus and its reintroduction into the present-day urban landscape. Rotterdam: 010 Publishers.

Ahmed, S. (2006). Queer phenomenology: Orientations, objects, others. Durham, NC: Duke University Press.

Amin, A., \& Thrift, N. (2002). Cities: Reimagining the urban. Cambridge: Polity.

Anderson, J., \& O'Dowd, L. (1999). Borders, border regions and territoriality: Contradictory meanings, changing significance. Regional Studies, 33(7), 593-604.

Augé, M. (1995). Non-places: An introduction to supermodernity. London and New York, NY: Verso.

Awan, N., Schneider, T., \& Till, J. (2011). Spatial agency: Other ways of doing architecture. Abingdon and Oxon: Routledge. 
Ballantyne, A. (2004). Misprisons of Stonhenge. In D. Arnold \& A. Ballantyne (Eds.), Architecture as experience: Radical change in spatial practice (pp. 11-35). London: Routledge.

Beauregard, R. (2005). From place to site: Negotiating narrative complexity. In C. J. Burns \& A. Kahn (Eds.), Site matters: Design concepts, histories, and strategies (pp. 39-58). New York, NY: Routledge.

Brook, I. (2000). Can 'spirit of place' be a guide to ethical building? In W. Fox (Ed.), Ethics and the built environment (pp. 139-152). London: Routledge.

Burns, C. J., \& Kahn, A. (2005). Why site matters. In C. J. Burns \& A. Kahn (Eds.), Site matters: Design concepts, histories, and strategies (pp. vii-xxiv). New York, NY: Routledge.

Cloke, P., Cook, I., Crang, P., Goodwin, M., Painter, J., \& Philo, C. (2004). Practising human geography. London: Sage.

Corner, J. (2011). The agency of mapping: Speculation, critique and invention. In M. Dodge, R. Kitchin, \& C. Perkin (Eds.), The map reader: Theories of mapping practice and cartographic representation (pp. 89-101). Chichester: Wiley-Blackwell.

Cornish, C. V. (1997). Behind the crumbling walls-the reworking of a former asylum's geography. Health \& Place, 3(2), 101-110.

Crouch, D. (2011). Flirting with space: Thinking landscape relationally. Cultural Geographies, 17(1), 5-18.

Dauphiné, A. (2012). Fractal geography. London: John Wiley.

Dovey, K. (2016). Urban design thinking. A conceptual toolkit. London: Bloomsbury.

Dürr, E., Egeb, M., Mosera, J., Neumann, C. K., \& Winder, G. M. (2020). Urban ethics: Towards a research agenda on cities, ethics and normativity. City, Culture and Society, 20. https://doi.org/10.1016/j.ccs.2019. 100313

Dyck, E., \& Deighton, A. (2017). Managing madness: Weyburn Mental Hospital and the transformation of psychiatric care in Canada. Manitoba: University of Manitoba Press.

Farias, I. (2010). Introduction: Decentering the object of urban studies. In I. Farias \& T. Bender (Eds.), Urban assemblages: How actor-network theory changes urban studies. Abingdon: Routledge.

Goffman, E. (1963). Stigma: Notes on the management of spoiled identity. Englewood Cliffs, NJ: PrenticeHall.

Grosz, E. (1992). Bodies-cities. In B. Colomina \& J. Bloomer (Eds.). (1992). Sexuality \& space. New York, NY: Princeton Architectural Press.

Hannah, M. G. (2019). Direction and socio-spatial theory: A political economy of oriented practice. London: Routledge.

Harvey, D. (2009). Cosmopolitanism and geographies of freedom. New York, NY, and Chichester: Columbia University Press.

Haselsberger, B. (2014). Decoding borders: Appreciating border impacts on space and people. Planning Theory and Practice, 14(4), 505-526.

Hillier, J. (2008). Plan(e) speaking: A multiplanar theory of spatial planning. Planning Theory, 7(1), 24-50.

Högström, E. (2012). Kalejdoskopiska rum: diskurs, materialitet och praktik i den decentraliserade psykiatriska vården [Kaleidoscopic spaces: Discourse, materiality and practice in decentralised mental health care] (Doctoral dissertation). Royal Institute of Technology, Stockholm, Sweden.

Högström, E. (2018). 'It used to be here but moved somewhere else': Post-asylum spatialisations: A new urban frontier? Social \& Cultural Geography, 19(3), 314-335.

Högström, E. (2020). Cities of relationships, not things. In J. Meijling \& T. Haas (Eds.), Essays on Jane Jacobs (pp. 51-72). Stockholm: Bokförlaget Stolpe.

Högström, E., \& Helms, G. (2019). Yielding and (not) breaking: Two observations on the walls of a psychiatric hospital. Architecture and Culture, 7(1), 45-49.

Jacobs, J. (1961). The death and life of great American cities. New York, NY: Vintage.

Lefebvre, H. (1991). The production of space. Oxford: Blackwell.

Massey, D. (2005). For space. London: Sage.

Metzger, J. (2014). Spatial planning and/as caring for more-than-human place. Environment and Planning A, 46(5), 1001-1011.

Moon, G., Kearns, R., \& Joseph, A. (2015). The afterlives of the psychiatric asylum-recycling concepts, sites and memories. Farnham and Burlington, VT: Ashgate.

Moser, I., \& Law, J. (1999). Good passages, bad passages. In J. Law \& J. Hassard (Eds.), Actor network theory and after (pp. 196-219). Oxford: Blackwell.

Paasi, A. (2009). Bounded spaces in a 'borderless world': Border studies, power and the anatomy of territory. Journal of Power, 2(2), 213-234.

Pacione, M. (1983). Neighbourhood communities in the modern city: Some evidence from Glasgow. Scottish Geographical Magazine, 99(3), 169-181.

Palasmaa, J. (2013). Mental and existential ecology. In R. Bhatt (Ed.), Rethinking aesthetics: The role of body in design. New York, NY: Routledge.

Parr, H. (2008). Mental health and social space: Inclusionary geographies? Oxford: Blackwell.

Philo, C. (2004). A geographical history of institutional provision for the insane from Medieval Times to the 1860s in England and Wales: 'The space reserved for insanity.' Lewiston, Queenston and Lampeter: Edwin Mellen Press.

Philo, C., \& Parr, H. (2019). Staying with the trouble of institutions. Area, 51(2), 241-248.

Popescu, G. (2011). Bordering and ordering the twentyfirst century: Understanding borders. Lanham, MD: Rowman \& Littlefield Publishers.

Sandercock, L. (2003). Out of the closet: The importance of stories and storytelling in planning practice. Planning Theory \& Practice, 4(1), 11-28. 
Sennett, R. (2018). Building and dwelling: Ethics for the city. London: Penguin Books.

Sibley, D. (1981). Outsiders in urban societies. Oxford: Blackwell.

Söderström, O. (2017). 'I don't care about places': The whereabouts of design in mental health care. In
C. Bates, R. Imrie, \& K. Kullman (Eds.), Care and design: Bodies, buildings, cities (pp. 56-73). Chichester: Wiley Blackwell.

Till, J. (2009). Architecture depends. Cambridge, MA: MIT Press.

\section{About the Authors}

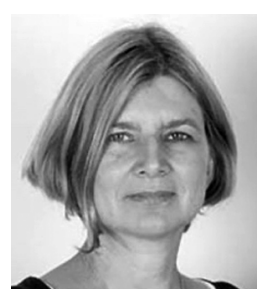

Ebba Högström is Researcher and Senior Lecturer at Spatial Planning at Blekinge Institute of Technology. Her research interest concerns social issues in urban planning and architecture, geographies of welfare, and experienced-based knowledge and methods. Currently, she is engaged in research projects addressing cross-sectoral collaboration in planning for housing provision for vulnerable groups and living environments of people with mental ill-health.

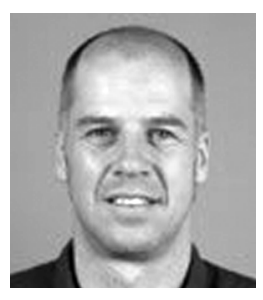

Chris Philo has been Professor of Geography at the University of Glasgow, Scotland, since 1995. He received his PhD from the University of Cambridge, England, in 1992. He is passionate about the value that a geographical perspective can bring to almost any academic inquiry. His specialist research is on the historical and social geographies of mental ill-health, psychiatric provisions and living with mental difference, and has also published widely on the history, theory, spirit and purpose of his 'home' discipline. 